\title{
Production of bacterial endoglucanase from pretreated oil palm empty fruit bunch by bacillus pumilus EB3
}

\begin{abstract}
In this study, endoglucanase was produced from oil palm empty fruit bunch (OPEFB) by a locally isolated aerobic bacterium, Bacillus pumilus EB3. The effects of the fermentation parameters such as initial $\mathrm{pH}$, temperature, and nitrogen source on the endoglucanase production were studied using carboxymethyl cellulose (CMC) as the carbon source. Endoglucanase from B. pumilus EB3 was maximally secreted at $37^{\circ} \mathrm{C}$, initial $\mathrm{pH} 7.0$ with 10 $\mathrm{g} / \mathrm{l}$ of $\mathrm{CMC}$ as carbon source, and $2 \mathrm{~g} / \mathrm{l}$ of yeast extract as organic nitrogen source. The activity recorded during the fermentation was $0.076 \mathrm{U} / \mathrm{ml}$. The productivity of the enzyme increased twofold when $2 \mathrm{~g} / \mathrm{l}$ of yeast extract was used as the organic nitrogen supplement as compared to the non-supplemented medium. An interesting finding from this study is that pretreated OPEFB medium showed comparable results to CMC medium in terms of enzyme production with an activity of $0.063 \mathrm{U} / \mathrm{ml}$. As OPEFB is an abundant solid waste at palm oil mills, it has the potential of acting as a substrate in cellulase production.
\end{abstract}

Keyword: endoglucanase, bacterial cellulase, Bacillus pumilus, oil palm empty fruit bunch 